FOLIA POMERANAE UNIVERSITATIS TECHNOLOGIAE STETINENSIS

Folia Pomer. Univ. Technol. Stetin., Oeconomica 2018, 347(93)4, 47-56

Paweł DZIEKAŃSKI, Piotr WIRASZKA ${ }^{1}$

\title{
THE FINANCIAL CONDITION OF EASTERN POLAND TOWNSHIPS AS A BARRIER TO THEIR DEVELOPMENT
}

\section{SYTUACJA FINANSOWA MIAST NA PRAWACH POWIATU POLSKI WSCHODNIEJ JAKO BARIERY ICH ROZWOJU}

Institute of Law, Economics and Administration, Jan Kochanowski University in Kielce, Świętokrzyska 21, 25-406 Kielce, Poland, ORCID: 0000-0003-4065-0043, e-mail: pdziekan@interia.eu ${ }^{1}$ Military Unit No. 4724, Tyniecka 45, 30-716 Kraków, Poland, e-mail: wiraszkapiotr@wp.pl

\begin{abstract}
Streszczenie. O wielowymiarowości procesu rozwoju świadczą kierunki działania powiatu jako lokalnego wielowymiarowego systemu współzależnych i powiązanych ze sobą czynników ekonomicznych, społecznych, infrastrukturalnych i naturalnych. W funkcjonowaniu jednostek samorządu terytorialnego specjalnego znaczenia nabiera zarządzanie środkami finansowymi. Celem artykułu jest analiza przestrzennych dysproporcji sytuacji finansowej miast na prawach powiatu Polski wschodniej. Jako materiał źródłowy wykorzystano dane z Bazy Danych Lokalnych Głównego Urzędu Statystycznego dla 2008, 2012 i 2016 r. Występująca polaryzacja regionu Polski Wschodniej, widoczna na poziomie powiatów, to utrzymanie się przewagi ośrodka ekspansywnego (lokalnego ośrodka wzrostu - Krosno, Kielce, Rzeszów, Olsztyn, Białystok). To także koncentracja działalności gospodarczej i społecznej w silnych regionalnie ośrodkach. Na drugim biegunie znalazły się Chełm, Przemyśl, Tarnobrzeg.
\end{abstract}

Key words: townships, Eastern Poland, synthetic measure, financial situation.

Słowa kluczowe: miara syntetyczna, Polska Wschodnia, powiaty grodzkie, sytuacja finansowa.

\section{INTRODUCTION}

Local economic system, as a complex system consisting of finance, infrastructure and environment, changes over time. The intensity of endogenous values of the region shapes the development process. However, public authorities are required to perform their role well, and their role is to create conditions that support sustainable development (Miłaszewicz 2013). Local development is affected by many factors, both dependent and independent of the municipality itself, among which financial situation is essential (Churski and in 2013). As Satoła (2015) states, there is no uniform definition of the term "financial condition" in literature. Speaking most broadly, "financial condition" can be defined as financial situation or the status of financial well-being (Siemińska 2002).

The financial situation of townships (cities with county or poviat rights) is closely correlated with the level of local development. It is understood as complex quantitative and qualitative transformations within the township referring to the residents' living standards and the functioning of business entities. The financial condition is reflected in inequalities in the form of ability to meet local needs (Kopyściański and Rólczyński 2014). A township's financial 
condition may be affected by its location (eg. location and size of local government units, available resources and natural assets, investment attractiveness), but might also be independent of it (eg. national and global economic fluctuations, public finance, income control and expenditure JST) (Dziekański 2014).

Townships are specific administrative units combining two forms: municipal government and county government. They perform tasks of both a county (poviat) and a municipality. They develop their own financial policy under the existing law within the bounds of financial autonomy they enjoy (Surówka 2013; Wyszkowska and Wyszkowski 2015).

The aim of the article is to analyze spatial differences in the distribution of finance between local government units using a synthetic measure.

\section{MATERIAL AND METHOD}

The analyzes included 14 townships (4 townsihips in the Lublin province, 4 in the Subcarpathia province, 3 in Podlaskie province, 1 in the Holy Cross province, and 2 in the Varmia-Masuria province) of Eastern Poland. As the source material data from the Local Data Base of the Central Statistical Office for 2008, 2012 and 2016 were used.

First, a selection and analysis of variables describing the financial situation were made. Variables characterized by low spatial variability and high correlating variables (according to the inverted matrix method) were removed. As Malina (2004) claims, high value of the correlation coefficient causes duplication of information about the analyzed phenomenon and may lead to incorrect conclusions.

In the next stage of the analysis, the procedure of resettlement using the following formulas was performed:

$$
\begin{aligned}
& z_{i j}=\frac{\mathrm{x}_{i j}-\min _{i} \mathrm{x}_{i j}}{\max _{i} \mathrm{x}_{i j}-\min _{i} x_{i j}}, \text { gdy } x_{i} \in S \\
& z_{i j}=\frac{\max _{i} \mathrm{x}_{i j}-\mathrm{x}_{i j}}{\max _{i} \mathrm{x}_{i j}-\min _{i} \mathrm{x}_{i j}}, \text { gdy } x_{i} \in D
\end{aligned}
$$

where:

$\mathrm{S}$ - stimulant, D - destimulant; i = 1, $2 \ldots \mathrm{n} ; \mathrm{j}=1,2 \ldots \mathrm{n}, \mathrm{xij}$ - means the value of the ,j" characteristic for the given unit, max - the maximum value of the ,j" feature, min - the minimal value of the „j” feature (Dziekański 2016, 2017; Mioduchowska-Jaroszewicz 2013; Wysocki 1996).

Next, the values of the synthetic measure for individual objects were determined. The first measure was determined based on the distance in the real space with the Euclidean metric in accordance with the formula:

$$
O E_{i t}=\sqrt{\frac{1}{p} \sum_{j=1}^{p}\left(1-z_{i j t}\right)^{2}}
$$

where (4) (3):

$\mathrm{i}=1,2 \ldots \mathrm{N} ; \mathrm{j}=1,2 \ldots, \mathrm{p}$ ( $\mathrm{N}$ is the number of objects (townships), $\mathrm{p}-$ the number of features); - means the value of the neutralizing feature for the examined unit, zij - is the value of the jth characteristic for the given unit, max - the maximum value of the jth feature, min - the minimum value of the j-th feature. The synthetic measure OE allows to measure reduced to the range $[0 ; 1]$. A measure value of 0 is the maximum positive value for the tested object (Wysocki 1996; Współczesne problemy ekonomiczne... 2013). 
The second synthetic measure according to the TOPSIS method was determined based on the formula:

$$
q_{i}=\frac{d_{i}^{-}}{d_{i}^{-}+d_{i}^{+}}
$$

where:

$0 \leq q_{i} \leq 1, i=1,2, \ldots, n ; d_{i}^{+}-$means the distance from the standard, the best unit in the studied population, $d_{i}^{-}-$the distance from the anti-clock device, qi $\in[0 ; 1]$; $\max i\{q i\}$ - the best object; mini $\{q i\}$ - the worst object. Value of a measure close to or equal to 1 means the best positive value for the objects of a given community (value 0 the weakest) (Hwang and Yoon 1981).

The synthetic measure allowed to categorize townships into four quartile groups. The size of the indicator in the first group means the better unit, the last one being the weakest. Cross-compliance of the results obtained was also verified based on the correlation coefficient. Clustering according to the Ward's method (minimizing within-cluster variation) was performed. A scatter plot with a fit line for synthetic measures is also presented (Dziekański 2013).

\section{DEVELOPMENT OF THE REGION AND ITS FINANCIAL SITUATION}

Regional level of development is an extremely complex concept and depends on both endogenous and exogenous factors of economic growth. Regions have become subjects of economic processes. They set the policy in place after giving consideration to local finance and resources, thereby representing and realizing the interests of local communities. As it comes to non-natural conditions, it is primarily the location in the socio-economic space. In terms of development potential, the settlement and communication network is particularly important (Ossowska and Poczta 2009). It is worth to point out that the analyzes carried out by Churski and co-authors (2013) and Stanny (2013) show that the crucial development factor is local finance. As Hendrick (2004) points out, financial condition of local governments cannot be measured focusing on one dimension only (one indicator). The local government's financial and fiscal health is tantamount to its ability to meet financial obligations in a timely manner and ensure continuity in providing services to the local community. The municipality's financial condition can serve as a platform to investigate how different factors affect it, and how successfully is the financial policy being implemented. Revenue and expenditure, tax and debt are a complex concept with different timeframes. These elements are interrelated, and so they must be analyzed and assessed collectively.

On the one hand, financial condition is the target of actions and the effect of decisions made and development opportunities associated with them. It is also influenced by: stable development strategy, available resources, skills, and resourcefulness of local authorities (Dylewski 2006). It can be treated as one of the endogenous factors of socio-economic development, and its high rating translates into improvement of the quality of life of local community. assessment thorough analysis of the financial condition allows local governments to manage to better manage the development process and the tasks they are responsible for. Such an analysis can be prepared for own needs and for external recipients (Filipiak 2006). 


\section{FINANCIAL CONDITION OF TOWNSHIPS LOCATED IN EASTERN POLAND}

Regional disparities in financial health have been found to be the characteristic feature. . The polarization of the Eastern Poland region, visible at the county level, is due to the expansive centre (local growth centre - Krosno, Kielce, Rzeszów, Olsztyn, and Białystok) maintaining its stronghold position. It is also due to the concentration of economic and social activity in strong regional centres.

The synthetic measure of financial health allowed to categorize townships of Eastern Poland into 4 quartile groups. Small shifts in time and space can be observed between groups.

In 2008, the synthetic measure of financial condition based on Euclidean metric ranged from 0,57 (Krosno, ranked highest unit, Subcarpathian province) - 0,80 (Przemyśl, the weakest unit, Subcarpathian province), in 2012 from 0,60 (Krosno) - 0,84 (Chełm, Lublin province) and in 2016 from 0,55 (Krosno) - 0,77 (Chełm). The synthetic measure based on the TOPSIS method in 2008 assumed values from 0,24 (Przemyśl, the weakest unit) to 0,48 (Krosno, the best unit), in 2012 from 0,20 (Chełm) to 0,45 (Krosno ) and in 2016 from 0,25 (Chełm) to 0,50 (Chełm). Regardless of the method of aggregation of the synthetic measure, Krosno, Rzeszów, Olsztyn, Białystok, and Kielce were highly ranked. Chełm, Przemyśl and Tarnobrzeg fell on the other extreme (Table 1).

Table 1. Quartile groups according to the measure of final condition of townships of Eastern Poland 2008, 2012 and 2016

\begin{tabular}{|c|c|c|c|c|c|c|}
\hline & \multicolumn{3}{|c|}{ Method OE } & \multicolumn{3}{|c|}{ Method TOPSIS } \\
\hline & 2008 & 2012 & 2016 & 2008 & 2012 & 2016 \\
\hline A & $\begin{array}{ll}\text { Krosno } & 0.57 \\
\text { Rzeszów } & 0.59 \\
\text { Olsztyn } & 0.62 \\
\text { Lublin } & 0.63\end{array}$ & $\begin{array}{ll}\text { Krosno } & 0.60 \\
\text { Rzeszów } & 0.62 \\
\text { Białystok } & 0.63 \\
\text { Olsztyn } & 0.63\end{array}$ & $\begin{array}{lc}\text { Krosno } & 0.55 \\
\text { Rzeszów } & 0.60 \\
\text { Olsztyn } & 0.61 \\
\text { Białystok } & 0.64 \\
\text { Kielce } & 0.64 \\
\text { Elbląg } & 0.64\end{array}$ & $\begin{array}{ll}\text { Krosno } & 0.48 \\
\text { Lublin } & 0.44 \\
\text { Rzeszów } & 0.44 \\
\text { Olsztyn } & 0.44\end{array}$ & $\begin{array}{ll}\text { Krosno } & 0.45 \\
\text { Rzeszów } & 0.40 \\
\text { Białystok } & 0.40 \\
\text { Kielce } & 0.40 \\
\text { Olsztyn } & 0.40\end{array}$ & $\begin{array}{ll}\text { Krosno } & 0.50 \\
\text { Olsztyn } & 0.47 \\
\text { Rzeszów } & 0.44 \\
\text { Białystok } & 0.41 \\
\text { Kielce } & 0.41\end{array}$ \\
\hline$B$ & \begin{tabular}{ll}
\multicolumn{3}{l}{ Białystok } & 0.64 \\
Kielce & 0.64 \\
Zamość & 0.66 \\
Elbląg & 0.67
\end{tabular} & $\begin{array}{ll}\text { Kielce } & 0.64 \\
\text { Lublin } & 0.67 \\
\text { Zamość } & 0.69\end{array}$ & $\begin{array}{ll}\text { Lublin } & 0.65 \\
\text { Łomża } & 0.65\end{array}$ & $\begin{array}{ll}\text { Kielce } \quad 0.42 \\
\text { Białystok } 0.41 \\
\text { Zamość } 0.40\end{array}$ & $\begin{array}{lr}\text { Lublin } & 0.37 \\
\text { Zamość } & 0.35\end{array}$ & $\begin{array}{ll}\text { Lublin } & 0.40 \\
\text { Łomża } & 0.40 \\
\text { Suwałki } & 0.40 \\
\text { Elbląg } & 0.40\end{array}$ \\
\hline C & $\begin{array}{ll}\text { Łomża } & 0.70 \\
\text { Lublin } & 0.37 \\
\text { Tarnobrzeg } 0.72 \\
\text { Suwałki } & 0.72\end{array}$ & 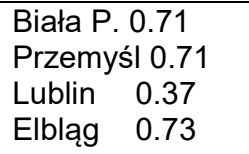 & $\begin{array}{ll}\text { Suwałki } & 0.66 \\
\text { Lublin } & 0.37\end{array}$ & $\begin{array}{ll}\text { Łomża } & 0.39 \\
\text { Elbląg } & 0.38 \\
\text { Lublin } & 0.37 \\
\text { Suwałki } & 0.32\end{array}$ & $\begin{array}{ll}\text { Przemyśl } 0.34 \\
\text { Biała P. } & 0.31 \\
\text { Lublin } & 0.37 \\
\text { Elbląg } & 0.31\end{array}$ & $\begin{array}{lr}\text { Lublin } & 0.37 \\
\text { Biała P. } 0.36\end{array}$ \\
\hline D & $\begin{array}{l}\text { Chełm } 0.79 \\
\text { Przemyśl } 0.80\end{array}$ & $\begin{array}{l}\text { Łomża } \quad 0.77 \\
\text { Tarnobrzeg } 0.78 \\
\text { Chełm } \quad 0.84\end{array}$ & $\begin{array}{l}\text { Tarnobrzeg } 0.71 \\
\text { Biała P. } 0.73 \\
\text { Przemyśl } 0.73 \\
\text { Chełm } 0.77\end{array}$ & $\begin{array}{l}\text { Tarnobrzeg } 0.31 \\
\text { Chełm } 0.25 \\
\text { Przemyśl } 0.24\end{array}$ & $\begin{array}{ll}\text { Tarnobrzeg } 0.27 \\
\text { Łomża } & 0.27 \\
\text { Chełm } & 0.20\end{array}$ & $\begin{array}{l}\text { Tarnobrzeg } 0.33 \\
\text { Przemyśl } 0.32 \\
\text { Chełm } 0.28\end{array}$ \\
\hline
\end{tabular}

Source: own study based on CSO BDL data.

Cluster analysis carried out using the Ward's method (based on Euclidean distance), indicates a similar division of townships of Eastern Poland in terms of synthetic financial condition indicator (according to the OE and TOPSIS methods). 3 bonds were distinguished (4, 3, 7 units) at the level of 0,2 as per the OE synthetic measure. As it comes to the TOPSIS - based clustering at level 0,2 3 bonds were distinguished. The first includes 7 units, the second one (Chełm), the third 6 units. Figure 1 presents a similar division into groups. There is a group with Lublin, Olsztyn, Białystok, Rzeszów and Kielce (Fig. 1). 

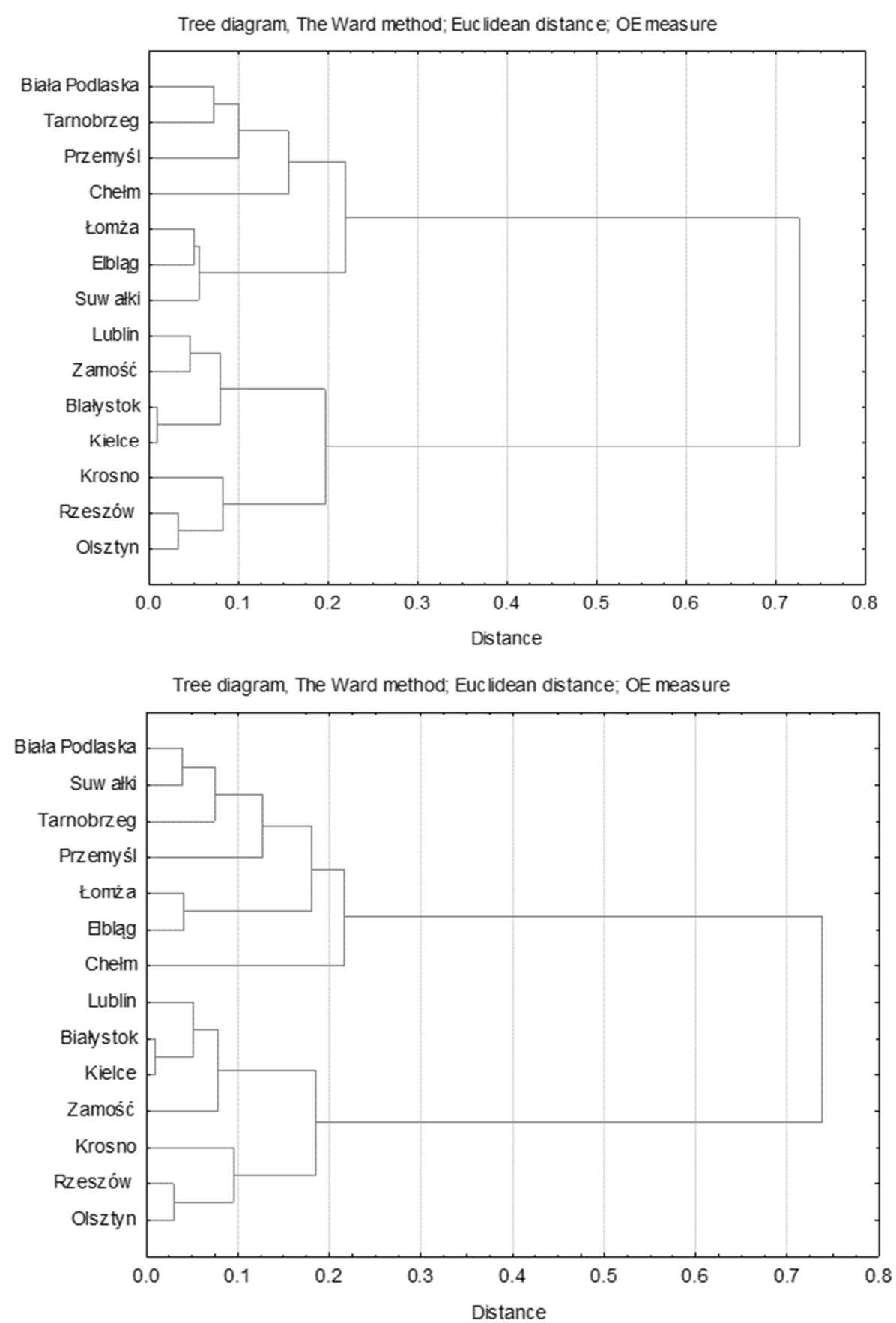

Fig. 1. Tree diagram of synthetic financial condition indicators Source: own study with the use of Statistica software.

The analysis of the variation in the measure of synthetic financial condition indicates that in 2016, in comparison to 2008, diversification remained on the same level (standard deviation $0.06-0.07$ for both designated synthetic measures), with a small decrease in the range from 0.23 in 2008 to 0.22 in 2016 for OE (for the measure TOPSIS 0.24-0.22). The classic coefficient of variation also indicates stability in the examined range (for the OE it was $0.10-0.09$, for TOPSIS $0.20-0.15$ in 2008 to 2016). In the examined years, the distribution of the synthetic measure value was characterized by right-sided asymmetry for OE. For TOPSIS measure - left-sided asymmetry (Table 2). 
Table 2. Diversification of the synthetic finance measure in 2008, 2012 and 2016

\begin{tabular}{|l|c|c|c|c|c|c|}
\cline { 2 - 7 } \multicolumn{1}{c|}{} & \multicolumn{3}{c|}{ Method OE } & \multicolumn{3}{c|}{ Method TOPSIS } \\
\cline { 2 - 7 } \multicolumn{1}{c|}{} & 2008 & 2012 & 2016 & 2008 & 2012 & 2016 \\
\hline Average & 0.68 & 0.70 & 0.66 & 0.37 & 0.34 & 0.39 \\
\hline Median & 0.67 & 0.70 & 0.65 & 0.40 & 0.35 & 0.40 \\
\hline Standard deviation & 0.07 & 0.07 & 0.06 & 0.07 & 0.07 & 0.06 \\
\hline Classic coefficient of variation & 0.10 & 0.10 & 0.09 & 0.20 & 0.20 & 0.15 \\
\hline Positional coefficient of variation & 0.07 & 0.07 & 0.05 & 0.15 & 0.13 & 0.06 \\
\hline Min & 0.57 & 0.60 & 0.55 & 0.24 & 0.20 & 0.28 \\
\hline Max & 0.80 & 0.84 & 0.77 & 0.48 & 0.45 & 0.50 \\
\hline Range (max-min) & 0.23 & 0.24 & 0.22 & 0.24 & 0.25 & 0.22 \\
\hline Slant & 0.38 & 0.53 & 0.12 & -0.60 & -0.45 & -0.10 \\
\hline
\end{tabular}

The obtained measures of correlation indicate high consistency of results generated with the use of the two methods of linear ordering and indicate a fairly stable spatial differentiation of the financial condition. The Pearson correlation coefficient of these measures in 2008, 2012 and 2016 was $-0.976,-0.989,-0.969$, which indicates a small degree of divergence (Table 3).

Table 3. Compatibility of results of measures of synthetic financial condition

\begin{tabular}{|l|c|c|c|c|}
\cline { 2 - 5 } \multicolumn{1}{c|}{} & \multicolumn{3}{c|}{ Correlation measure } \\
\cline { 2 - 5 } \multicolumn{1}{c|}{} & Pearson & Spearman & Gamma & tau Kendala \\
\hline OE 2008-2012 & 0.822 & 0.847 & 0.741 & 0.715 \\
\hline OE 2012-2016 & 0.786 & 0.762 & 0.670 & 0.651 \\
\hline OE-TOPSIS 2008 & -0.976 & -0.986 & 0.976 & 0.942 \\
\hline OE-TOPSIS 2012 & -0.989 & -0.981 & -0.999 & 0.942 \\
\hline OE-TOPSIS 2016 & -0.969 & -0.967 & 0.950 & 0.905 \\
\hline TOPSIS 2008-2012 & 0.711 & 0.827 & 0.721 & 0.679 \\
\hline TOPSIS 2012-2016 & 0.811 & 0.820 & 0.763 & 0.703 \\
\hline
\end{tabular}

Source: own study with the use of Statistica software

In the analyzed time interval Pearson's correlation coefficients in relation to synthetic measures determined by selected methods were in $2008 r=-0.976 / r^{2}=0.954$, in 2012 $r=-0.989 / r^{2}=0.979$ and in $2016 r=-0.969 / r^{2}=0.939$. This proves that each of the analyzed measures reveal a similar classification of communes with minor spatial diversity (Figure 2).

Pearson's correlation coefficients in the analyzed time interval (2012-2008, 2016-2012) with regard to the ratio of synthetic measures determined by selected methods was respectively for the OE: $r=0,822 / r^{2}=0,676$ and $r=0,786 / r^{2}=0,619$ and for TOPSIS: $r=0,771 / r^{2}=0,595$ and $r=0,811 / r^{2}=0,658$. The graph indicates the bipolarity of changes, and the distinguishing ones are Łomża, Chełm, Przemyśl, Biała Podlaska and Krosno (Figure 3). 

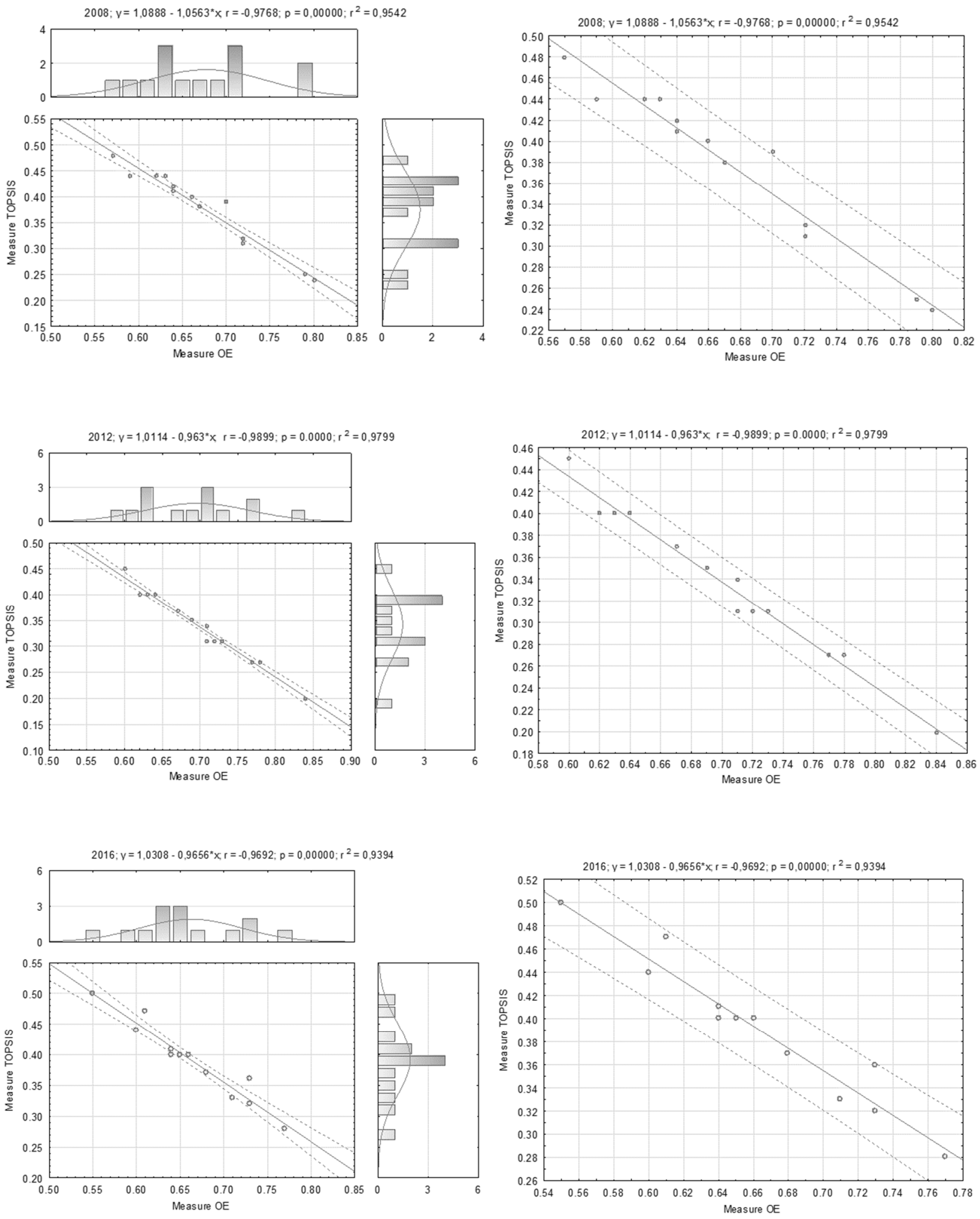

Fig. 2. Scatter plot of synthetic measure with a fit line Source: own study with the use of Statistica software. 

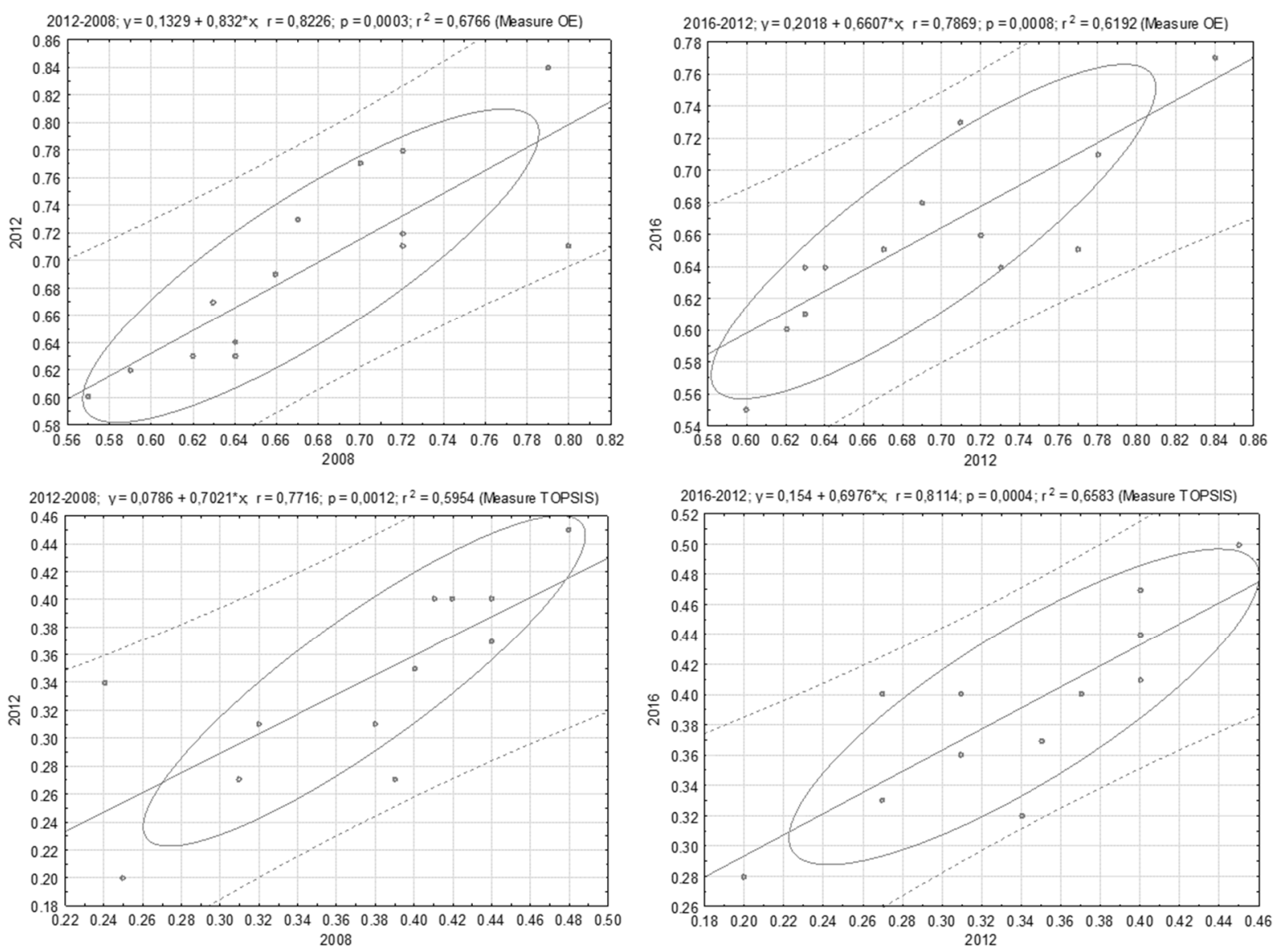

Fig. 3. A graph of the synthetic measure scattering with the year-to-year adjustment line Source: own study with the use of Statistica software.

\section{CONCLUSION}

The multidimensional nature of the development process is manifested in the activities of townships (cities with county or poviat rights) understood as a local complex system of interdependent and interrelated economic, social, infrastructural and natural factors.

Financial resources available to local governments affect local governments' overall economic situation and the implementation of municipal tasks. Moreover, the resources determine the pace of development on the one hand, and on the other, are an expression of the potential for economic growth. Efficient management of finance by local government units is crucial to the welfare of townships.

The situation of the surveyed units varied. The ranking of townships did not change substantially in the subsequent years. The polarization of the Eastern Poland region, visible at the county level, is due to the expansive centre (local growth centre - Krosno, Kielce, Rzeszów, Olsztyn, and Białystok) maintaining its stronghold position. It is also due to the concentration of economic and social activity in strong regional centres. This is why such townships Chełm, Przemyśl and Tarnobrzeg fall on the other end of the spectrum. 


\section{REFERENCE}

Churski P., Borowczak A., Dolata M., Dominiak J., Hauke J., Perdał R., Konecka-Szydłowska B. 2013. Czynniki rozwoju obszarów wzrostu i obszarów stagnacji gospodarczej w Polsce. Raport IV. Poznań, UAM. [in Polish]

Dylewski M. 2006. Kierunki prowadzenia analizy finansowej w procesie zarządzania finansami, w: Finanse samorządowe. Narzędzia, decyzje, procesy. Red. M. Dylewski, B. Filipiak, M. Gorzałczyńska-Koczkodaj. Warszawa, Wydaw. Nauk. PWN, 144-151. [in Polish]

Dziekański P. 2013. Wskaźnik syntetyczny w procesie oceny gospodarki finansowej gmin wiejskich [Synthetic index of financial management assessment of rural communities]. Ekonomia 3(24), 148-163. [in Polish]

Dziekański P. 2014. Koncepcja wskaźnika syntetycznego do oceny sytuacji finansowej powiatów [Concept of synthetic indicator for the assessment of financial situation of poviats]. Res. Pap. Wroc. Univ. Econ. 329, 98-108. [in Polish]

Dziekański P. 2016. Spatial differentiation of the financial condition of the Świętokrzyskie Voivodship Counties. Barometr Reg. 14, 3(45), 89-101.

Dziekański P. 2017. Diversification synthetic indicator for evaluating the financial capacity of local government. The case of polish voivodeships. Acta Univ. Agric. Silv. Mendel. Brunen. 65(2), 611-619.

Filipiak B. 2006. Analiza finansowa i jej znaczenie w zarządzaniu finansami, w: Finanse samorządowe. Narzędzia, decyzje, procesy. Red. M. Dylewski, B. Filipiak, M. Gorzałczyńska-Koczkodaj. Warszawa, Wydaw. Nauk. PWN, 138-143. [in Polish]

Hendrick R. 2004. Assessing and measuring the fiscal heath of local governments. Focus on Chicago Suburban Municipalities, Urban Affaires Rev. 40(1), 78-114

Kopyściański T., Rólczyński T. 2014. Analiza wskaźników opisujących sytuację finansową powiatów w województwie dolnośląskim w latach 2006-2012 [Analysis of indicators describing the financial position of lower silesia poviats in the period of 2006-2012]. Stud. Ekon. Katowice 206, 61-62. [in Polish]

Malina A. 2004. Wielowymiarowa analiza przestrzennego zróżnicowania struktury gospodarki Polski według województw. Kraków, Wydaw. AE, 96-97. [in Polish]

Miłaszewicz D. 2013. Wolność ekonomiczna i sposób rządzenia jako uwarunkowania zrównoważonego rozwoju Studia Ekonomiczne [Economic Freedom and Governance as a Determinants Sustainable Development]. Studia Ekonomiczne. Zeszyty Naukowe Uniwersytetu Ekonomicznego w Katowicach. nr 139. 101-111.

Mioduchowska-Jaroszewicz E. 2013. Metody i kierunki oceny kondycji finansowej jednostek samorządów terytorialnych [Methods and Directions of the Financial Position of UnitsoOf Local Self-Governments]. Zesz. Nauk. USzczec. Finanse, Ubezpieczenia 64(2), 127-140. [in Polish]

Ossowska L., Poczta W. 2009. Endogenne uwarunkowania rozwoju społeczno-gospodarczego obszarów wiejskich Pomorza Środkowego. Poznań, Wydaw. Uniw. Przyr. w Poznaniu, 34-63. [in Polish]

Satoła Ł. 2015. Kondycja finansowa gmin w warunkach zmiennej koniunktury gospodarczej [The financial condition of municipalities in variable economic situation]. J. Agrobus. Rural Develop 1(35), 115-123. [in Polish]

Siemińska E. 2002. Metody pomiaru i oceny kondycji finansowej przedsiębiorstwa. Toruń, Wydaw. Dom Organizatora. [in Polish]

Stanny M. 2013. Przestrzenne zróżnicowanie rozwoju obszarów wiejskich w Polsce. Warszawa, IRWiR PAN. [in Polish]

Statystyczna analiza przestrzennego zróżnicowania rozwoju ekonomicznego i społecznego Polski. 2013. Red. M. Trojak, T. Tokarski. Kraków, Wydaw. UJ. [in Polish]

Surówka K. 2013. Samodzielność finansowa samorządu terytorialnego w Polsce. Warszawa, PWE, 21-27. [in Polish] 
Wysocki F. 1996. Metody statystycznej analizy wielowymiarowej w rozpoznawaniu typów struktury przestrzennej rolnictwa [Methods of statistical multidimensional analysis in recognizing the types of spatial structure of agriculture]. Rocz. AR Pozn., Ser. Rozpr. Nauk. 266.

Wyszkowska D., Wyszkowski A. 2015. Samodzielność dochodowa samorządu terytorialnego w Polsce [Self-government revenue autonomy in Poland]. Stud. Mater. Miscellanea Oeconom. 2, 131-142. [in Polish]

Summary. The multidimensional nature of the development process is manifested in the activities performed by townships (cities with county or poviat rights) and understood as a complex local system of interdependent and interrelated economic, social, infrastructural and natural factors. In the functioning of local government units, the management of financial resources is of special importance. The aim of the article is to analyze the financial disparity between townships in Eastern Poland. The data from the Local Data Base of the Central Statistical Office for 2008, 2012 and 2016 were used as source material. The polarization of the Eastern Poland region, visible at the county level, is due to the expansive centre (local growth centre - Krosno, Kielce, Rzeszow, Olsztyn, Bialystok) maintaining its stronghold position. It is also due to the concentration of economic and social activity in strong regional centres. This is why such townships as Chelm, Przemysl and Tarnobrzeg fall on the other end of the spectrum. 